\title{
Studies on Bunch Feeding on Yield, Post-Harvest Parameters and B: C Ratio in Banana cv. Rajapuri (Musa AAB)
}

\author{
Soumya M. Garasangi*, S.I. Athani, Hipparagi, Kulapati, T.B. Allolli, \\ J.B. Gopali and Mallikarjun Awati \\ University of Horticultural Sciences, Bagalkot, Karnataka, India \\ *Corresponding author
}

\section{A B S T R A C T}

\section{Keywords \\ Post-Harvest parameters, $\mathrm{B}$ : C ratio, \\ Banana cv. Rajapuri (Musa AAB) \\ Article Info \\ Accepted: \\ 26 January 2018 \\ Available Online: \\ 10 February 2018}

\begin{abstract}
An investigation consisting of bunch feeding on banana cv. Rajapuri (Musa AAB) was conducted during 2016-17 in the farmers field in Tadasalur village in Savadatti taluk of Belgaum district. Bunch fed with combination of $500 \mathrm{ml}$ of cow dung slurry and $20 \mathrm{~g}$ of $\mathrm{K}_{2} \mathrm{SO}_{4}$ increased the characters viz., bunch weight $(13.20 \mathrm{~kg})$, total yield (14.66 tonnes/ ha), green life (12.67 days), shelf life (9.00 days), benefit: cost ratio (2.28:1) and reduced titrable acidity $(0.24 \%)$ and physiological loss in weight $(15.34 \%)$. For most of the yield, post-harvest, quality parameters and benefit: cost ratio the minimum values were recorded in $\mathrm{T}_{10}$ (Control). Thus, the study clearly indicates that bunch feeding with $500 \mathrm{ml}$ of cow dung slurry and $20 \mathrm{~g}$ of $\mathrm{K}_{2} \mathrm{SO}_{4}$ improves the yield parameters, post-harvest parameters and $\mathrm{B}$ : $\mathrm{C}$ ratio in banana cv. Rajapuri (Musa AAB).
\end{abstract}

\section{Introduction}

Banana is one of the important fruit crop of India. The name banana comes from the Arabic word 'BANANA', which means finger. Banana is also known by other synonyms like 'Adam's fig', 'Kalpataru', 'Tree of wisdom' and 'Apple of Paradise'. Banana (Musa spp) is one of the major commercial fruit crops grown in the tropics, subtropics and plays a key role in the economy of developing countries. It is one of the most important fruit crops of India, which is cultivated throughout the year. Among the banana varieties grown in India, the cultivar 'Rajapuri' belongs to the Musa AAB group is one of the popular varieties among growers and consumers, particularly in Karnataka and Kerala for domestic markets. Banana has many varieties but among those, local or indigeneous cultivars are more tolerant to biotic and abiotic stresses and suitable to local agro-climatic conditions, also require lesser inputs like FYM, compost, fertilizer and water to obtain satisfactory yield and banana cv. Rajapuri is one among the local banana cultivated mainly in the northern parts of Karnataka.

Generally, photosynthates move from the source to the sink i.e. leaves to developing bunches determine total yield. Hence, any limitations in the supply of photosynthates at 
this crucial state affect the bunch size and quality. Because of this problem, poor filling and development of fingers is often reported in all most all cultivars of commercial importance. In addition to the soil application and foliar application of nutrients, the nutrients can also be supplied through direct feeding of the bunches through cut rachis after denavelling. This involves the use of various combinations of hormonal and nutrient resources as well as cultural operations in order to increase bunch yield and improve finger characters. Development of bunch feeding practices benefits the growers for increasing and sustaining productivity and income. Under commercial cultivation, bunch size in banana is manipulated to enhance the size of fingers to suit market demands in South-East Asian countries. Nutrients are supplied to the banana plant through soil and foliage, by de-navelling (removal of male inflorescence) and feeding nutrients post shooting through the distal stalk-end of rachis (Ancy and Kurein, 2000). De-navelling serves the twin purpose of saving mobilization of food into an unwanted sink plant and earning an additional income when the excised male bud is used as vegetable. Further, it also facilitates bunch feeding with nutrients through cut end of rachis (Singh, 2001). Further, the fruit quality is determined by size (finger length and finger girth), evenness of ripening, free from blemishes and defects and arrangement of hands are also favorably influenced by this technique. Hence, the technology of bunch feeding in banana is very useful in improving the yield and quality of the fruit.

\section{Materials and Methods}

The research was conducted during 2016-17, in the farmer's field at Tadasalur, near Yaragatti, Savadatti taluq, Belgaum district in banana cv. Rajapuri. The experiment was laid out in a Randomized Complete Block Design
(RCBD) with ten treatments, replicated thrice. The treatment details are

$\mathrm{T}_{1}: 500 \mathrm{ml}$ of cow dung slurry $+20 \mathrm{~g}$ of $\mathrm{KNO}_{3}$

$\mathrm{T}_{2}: 500 \mathrm{ml}$ of cow dung slurry $+10 \mathrm{~g}$ of Urea

$\mathrm{T}_{3}: 500 \mathrm{ml}$ of cow dung slurry $+20 \mathrm{~g}$ of $\mathrm{K}_{2} \mathrm{SO}_{4}$

$\mathrm{T}_{4}: 500 \mathrm{ml}$ of cow dung slurry $+25 \mathrm{mg}$ of $\mathrm{GA}_{3}$

$\mathrm{T}_{5}: 500 \mathrm{ml}$ of cow dung slurry $+15 \mathrm{mg}$ of 2 , 4-D

$\mathrm{T}_{6}: 500 \mathrm{ml}$ of cow dung slurry $+12.5 \mathrm{~g}$ of Sulphate of potash (SOP)

$\mathrm{T}_{7}: 500 \mathrm{ml}$ of cow dung slurry $+10 \mathrm{~g}$ of Ammonium sulphate

$\mathrm{T}_{8}: 500 \mathrm{ml}$ of cow dung slurry

$\mathrm{T}_{9}: 500 \mathrm{ml}$ of cow dung slurry $+10 \mathrm{~g}$ of Urea $+20 \mathrm{~g}$ of $\mathrm{K}_{2} \mathrm{SO}_{4}+15 \mathrm{mg}$ of $\mathrm{GA}_{3}$

$\mathrm{T}_{10}$ : Control (without bunch stalk feeding)

The prepared solution was placed in the thick polythene bag and tied to the cut end of denavelled bunch immediately. The denavelling was carried out soon after all the pistillate flowers have set fruits i.e., 15 days after flower emergence and maintained till harvest.

\section{Study parameters included}

The parameters included are bunch weight $(\mathrm{Kg})$, total plant yield (t/ha), green life (days), shelf life (days), physiological loss in weight (\%) and benefit cost ratio. The bunch weight was recorded after harvest of fully matured bunches of tagged plants. Bunches were cut when fingers had fully developed and devoid of any ridges on its surface of the fruit and 
weighed and the bunch weight was expressed in kilogram. The yield per hectare was calculated by multiplying the yield per plant (bunch weight/plant) with the total number of harvested bunches per hectare and expressed in tonnes per hectare. The fully matured hands were taken and kept for ripening under ambient condition and the days taken for change of colour from green to yellow was recorded. Shelf life of fruits was decided based on the appearance and marketability of the fruits. The shelf life of fruits was determined by recording the number of days the fruits remained in good condition in storage. The stage where in more than 50 per cent of the stored fruits became unfit for consumption was considered as end of shelf life in that particular treatment and expressed as mean number of days. The physiological loss in weight of fruit was expressed in per cent loss of weight from day of harvest to the end of shelf life.

\section{Initial weight - Weight at the end of the} Shelf life

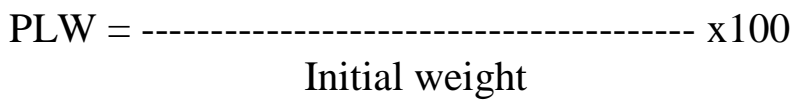

The benefit-cost ratio for the different treatments was worked out based on the expenditure and return in order to study the economics of banana production. The data with respect to all the above parameters were tabulated and subjected to the statistical analysis using methods of analysis of variance (ANOVA) for randomized block design by Fisher and Yates (1963). Whenever, ' $F$ ' test was found significant for comparing the means of two treatments the critical difference (CD at 5\%) was worked out.

\section{Results and Discussion}

The results obtained from the present investigation, on yield parameters viz., bunch weight and yield per hectare revealed that, there was a significant difference among the treatments. The treatment $\mathrm{T}_{3}$ - bunch fed with dipping the cut end in the $500 \mathrm{ml}$ of cow dung slurry $+20 \mathrm{~g}$ of $\mathrm{K}_{2} \mathrm{SO}_{4}$ recorded the highest bunch weight $(13.20 \mathrm{~kg})$ and yield $(14.66 \mathrm{t} / \mathrm{ha})$ (Table 1), whereas minimum bunch weight and yield per hectare was noticed in T10 control $(9.33 \mathrm{~kg}$ and10.36 t/ha respectively). In the present study, application of sulphate of potash improved bunch weight and yield per hectare and the findings are in corroboration with the results of Pandey and Sinha (1999), who have reported that the increase in weight of the bunch and yield per hectare are due to sulphur present in the sulphate of potash which might be responsible for the formation of ferridoxin (iron-sulphur protein) in plants which might have a direct impact in activating the catalase and peroxidase enzymes. Sulphur application increased the yield since it is a constituent of amino acid and protein production (Ahmed et al., 1998). This was in corroboration with the findings of Sandhya et al., (2016) in banana cv. Grand Naine.

All the post-harvest parameters differed significantly among the treatments (Table 2). The highest green life (12.67 days), days taken for ripening (9.00) with minimum physioiogical loss in weight (15.34) of fruits was recorded in $\mathrm{T}_{3}$ - bunch fed with $500 \mathrm{ml}$ of cow dung slurry and 20 gm of $\mathrm{K}_{2} \mathrm{SO}_{4}$,

In the present experiment, more number of days to turn yellow colour was observed which might be due to lesser PLW experinced in fruits of those treated with $\mathrm{T}_{3}$ (bunch fed with $500 \mathrm{gm}$ of cowdung and $20 \mathrm{~g}$ of $\mathrm{K}_{2} \mathrm{SO}_{4}$ ). This can also be attributed to increase in peel thickness of the fruits, which resulted in firmness of the fruits. Increase in green life of fruit might be due to reduced rate of respiration and ethylene production by potassium application, as reported by Singh and Chuhan (1982). 
Table.1 Effect of bunch feeding on yield parameters of banana cv. Rajapuri

\begin{tabular}{|c|c|c|}
\hline Treatment & $\begin{array}{l}\text { Bunch } \\
\text { weight }(\mathbf{k g})\end{array}$ & Yield (t/ha) \\
\hline $\mathrm{T}_{1}$ : Cow dung slurry $500 \mathrm{ml}+\mathrm{KNO}_{3} 20 \mathrm{~g}$ & 12.73 & 14.14 \\
\hline $\mathrm{T}_{2}:$ Cow dung slurry $500 \mathrm{ml}+$ Urea $10 \mathrm{~g}$ & 11.91 & 13.23 \\
\hline $\mathrm{T}_{3}$ : Cow dung slurry $500 \mathrm{ml}+\mathrm{K}_{2} \mathrm{SO}_{4} 20 \mathrm{~g}$ & 13.20 & 14.66 \\
\hline $\mathrm{T}_{4}$ : Cow dung slurry $500 \mathrm{ml}+\mathrm{GA}_{3} 25 \mathrm{mg}$ & 10.86 & 12.07 \\
\hline $\mathrm{T}_{5}:$ Cow dung slurry $500 \mathrm{ml}+2,4-\mathrm{D} 15 \mathrm{mg}$ & 10.96 & 12.18 \\
\hline $\mathrm{T}_{6}:$ Cow dung slurry $500 \mathrm{ml}+\mathrm{SOP} 12.5 \mathrm{~g}$ & 13.11 & 14.56 \\
\hline $\mathrm{T}_{7}$ : Cow dung slurry $500 \mathrm{ml}+$ ammonium sulphate $10 \mathrm{~g}$ & 13.06 & 14.50 \\
\hline T. $_{8}$ Cow dung slurry $500 \mathrm{ml}$ & 13.11 & 14.56 \\
\hline $\begin{array}{l}\text { T9: Cow dung slurry } 500 \mathrm{ml}+10 \mathrm{~g} \text { urea }+20 \mathrm{~g} \mathrm{~K}_{2} \mathrm{SO}_{4}+ \\
25 \mathrm{mg} \mathrm{GA}\end{array}$ & 11.17 & 12.41 \\
\hline $\mathrm{T}_{10}$ : Control (Without bunch stalk feeding) & 9.33 & 10.36 \\
\hline S.Em \pm & 0.70 & 0.64 \\
\hline CD at $5 \%$ & 2.07 & 1.91 \\
\hline
\end{tabular}

Table.2 Effect of bunch feeding on post-harvest parameters of banana cv. Rajapuri

\begin{tabular}{|c|c|c|c|}
\hline Treatment & $\begin{array}{l}\text { Green life } \\
\text { (days) }\end{array}$ & $\begin{array}{l}\text { Shelf life } \\
\text { (days) }\end{array}$ & PLW (\%) \\
\hline $\mathrm{T}_{1}:$ Cow dung slurry $500 \mathrm{ml}+\mathrm{KNO}_{3} 20 \mathrm{~g}$ & 11.67 & 5.67 & 18.67 \\
\hline $\mathrm{T}_{2}$ : Cow dung slurry $500 \mathrm{ml}+$ Urea $10 \mathrm{~g}$ & 9.67 & 6.67 & 21.48 \\
\hline $\mathrm{T}_{3}:$ Cow dung slurry $500 \mathrm{ml}+\mathrm{K}_{2} \mathrm{SO}_{4} 20 \mathrm{~g}$ & 12.67 & 9.00 & 15.34 \\
\hline $\mathrm{T}_{4}:$ Cow dung slurry $500 \mathrm{ml}+\mathrm{GA}_{3} 25 \mathrm{mg}$ & 9.67 & 5.33 & 24.00 \\
\hline $\mathrm{T}_{5}:$ Cow dung slurry $500 \mathrm{ml}+2,4-\mathrm{D} 15 \mathrm{mg}$ & 11.00 & 6.67 & 18.90 \\
\hline $\mathrm{T}_{6}:$ Cow dung slurry $500 \mathrm{ml}+\mathrm{SOP} 12.5 \mathrm{~g}$ & 11.00 & 7.33 & 15.48 \\
\hline $\begin{array}{l}\mathrm{T}_{7}: \text { Cow dung slurry } 500 \mathrm{ml}+\text { ammonium } \\
\text { sulphate } 10 \mathrm{~g}\end{array}$ & 12.33 & 7.33 & 26.22 \\
\hline $\mathrm{T}_{8}:$ Cow dung slurry $500 \mathrm{ml}$ & 12.67 & 5.00 & 22.39 \\
\hline $\begin{array}{l}\mathrm{T}_{9}: \text { Cow dung slurry } 500 \mathrm{ml}+10 \mathrm{~g} \text { urea }+20 \\
\mathrm{~g} \mathrm{~K}_{2} \mathrm{SO}_{4}+25 \mathrm{mg} \mathrm{GA}\end{array}$ & 9.67 & 4.33 & 24.45 \\
\hline $\mathbf{T}_{10}:$ Control (Without bunch stalk feeding) & 8.67 & 3.67 & 31.01 \\
\hline S.Em \pm & 0.59 & 0.38 & 2.37 \\
\hline CD at $5 \%$ & 1.75 & 1.12 & 7.03 \\
\hline
\end{tabular}


Table.3 Effect of bunch feeding on benefit: cost ratio of banana cv. Rajapuri

\begin{tabular}{|c|c|c|c|c|c|c|c|}
\hline $\begin{array}{c}\text { Tr. } \\
\text { No. }\end{array}$ & $\begin{array}{c}\text { Fruit } \\
\text { yield } \\
(\mathbf{t} / \mathbf{h a})\end{array}$ & $\begin{array}{c}\text { Chemical } \\
(₹)\end{array}$ & $\begin{array}{c}\text { Labour } \\
(₹)\end{array}$ & $\begin{array}{c}\text { Total cost } \\
(₹)\end{array}$ & $\begin{array}{c}\text { Gross } \\
\text { income } \\
(₹)\end{array}$ & $\begin{array}{c}\text { Net return } \\
(₹)\end{array}$ & $\begin{array}{c}\text { Benefit: } \\
\text { Cost ratio }\end{array}$ \\
\hline $\mathbf{T}_{\mathbf{1}}$ & 14.14 & 5,560 & 1,500 & $1,97,806$ & $4,24,200$ & $2,26,394$ & $2.14: 1$ \\
\hline $\mathbf{T}_{\mathbf{2}}$ & 13.23 & 55.6 & 1,500 & $1,92,301.6$ & $3,96,900$ & $2,04,598$ & $2.06: 1$ \\
\hline $\mathbf{T}_{\mathbf{3}}$ & 14.66 & $1,045.28$ & 1,500 & $1,93,291.28$ & $4,39,800$ & $2,46,508$ & $2.28: 1$ \\
\hline $\mathbf{T}_{\mathbf{4}}$ & 12.07 & $1,890.4$ & 1,500 & $1,94,136.4$ & $3,62,100$ & 16,796 & $1.86: 1$ \\
\hline $\mathbf{T}_{\mathbf{5}}$ & 12.18 & 5.33 & 1,500 & $1,92,251.34$ & $3,65,400$ & $1,73,148$ & $1.90: 1$ \\
\hline $\mathbf{T}_{\mathbf{6}}$ & 14.56 & 653.3 & 1,500 & $1,92,899.3$ & $4,36,800$ & $2,43,900$ & $2.26: 1$ \\
\hline $\mathbf{T}_{\mathbf{7}}$ & 14.50 & 173.47 & 1,500 & $1,92,419.47$ & $4,35,000$ & $2,42,580$ & $2.26: 1$ \\
\hline $\mathbf{T}_{\mathbf{8}}$ & 14.56 & 0 & 1,500 & $1,92,246$ & $4,36,800$ & $2,44,554$ & $2.27: 1$ \\
\hline $\mathbf{T}_{\mathbf{9}}$ & 12.41 & $2,991.28$ & 1,500 & $1,95,237.28$ & $3,72,300$ & $1,77,062.72$ & $1.90: 1$ \\
\hline $\mathbf{T}_{\mathbf{1 0}}$ & 10.36 & 0 & 0 & $1,90,746$ & $3,10,800$ & $1,20,054$ & $1.62: 1$ \\
\hline
\end{tabular}

In addition to this, potassium element is also responsible for maintaining cytokinin level concentration in the plants which delays senescence, inturn contributing to enhanced green life (Bose et al., 1988). The number of days required from fully ripening of fruits to spoilage is the shelf life. The $\mathrm{T}_{3^{-}}$banana bunch fed with $500 \mathrm{ml}$ of cow dung slurry and $20 \mathrm{~g}$ of $\mathrm{K}_{2} \mathrm{SO}_{4}$ recorded the longest shelf life (9.00 days). This could be attributed to the potassium nutrient supplied through bunch feeding enhances storage and shipping quality of bananas and also extends their shelf life (Mengel, 1997). Nandankumar et al., (2011) in cv. Nanjangudu rasabale and Sateeshkumar and Bangaruswamy (2006) in cv. Rasthali (Table 2). The results pertaining to the physiological loss in weight of fruits differed significantly among treatments (Table 2 ). The highest PLW (31.01\%) of fruits was recorded in $\mathrm{T}_{10^{-}}$in plants bunch feeding was not carried out. While, the lowest PLW (15.34 \%) was noticed in the $\mathrm{T}_{3}$ - bunch fed with $500 \mathrm{ml}$ of cow dung slurry and $20 \mathrm{~g}$ of $\mathrm{K}_{2} \mathrm{SO}_{4}$. Reduced PLW might be due to the improvement in number of phellem layers and more number of crystals in phellem cells and scattered starch granules throughout the parenchyma, which reduced the rate of transpiration. The reduction in transpiration was helpful in improving the storability by reducing weight loss (Ravichandran et al., 2011). Weight loss from harvested fruits i.e. PLW, especially under tropical conditions causes severe loss to the producer and seller which also leads to quality deterioration with low consumer preference (Swietilk and Faust, 1984). This was in corroboration with the result findings of Ramesh Kumar et al., (2008) in cv. Robusta (AAA-Cavendish).

In the present investigation results on benefit: cost ratio is presented in Table $3 . \mathrm{T}_{3^{-}}$bunch fed with $500 \mathrm{ml}$ of cow dung slurry and $20 \mathrm{~g}$ of $\mathrm{K}_{2} \mathrm{SO}_{4}$ excelled maximum hand weight, bunch weight and yield per hectare there by recorded the highest benefit: cost ratio (2.28:1). It was due to sulphate of potash which is an important nutrient and amount of nutrient required in greater extent for increasing the bunch characters and yield attributes. The present investigation was in agreement with the findings of Ramesh Kumar and Kumar (2007) in which they reported that post-shooting spray of sulphate of potash (SOP) at $1.5 \%$ twice recorded the highest benefit: cost ratio in banana cv. Robusta. 


\section{References}

Ahmed, M. K., Aditya, D. K. and Siddique, M. A., 1998, Effect of $\mathrm{N}$ and $\mathrm{S}$ application on the growth and yield of onion cv. Faridpur Bhatti. Bangladesh Hort., 16(1): 36-41.

Ancy, K. and Kurien, S., 2000, Bunch stalk feeding of urea in banana Musa (AAB group) 'Nendran'. Sci. Hort., 84: 205-212.

Anonymous, 1984, Official Methods of Analysis. ED. Sioney Williams, Association of Official Analytical Chemists, Virginia, $14^{\text {th }}$ Edition, pp. 423-462.

Bose, T.K., Mithra, S.K. and Sadhu, M.K., 1988, Mineral nutrition of fruit crops. Published by B Mithra Naya Prakash, pp.15-16.

Fisher and Yates

Mengel, K., 1997, In food security in the WANA region, the essential need for balance fertilization (Ed. A. E. Johnston). Proc. Regional Workshop, Bornova, Izmir, Turkey, 26-30 May 1997. IPI Bern, Switzerland. pp. 157-74.

Nandankumar, C. P., Sathyanarayana, B. N., Naresh, P. and Lakshmipathy, M., 2011, Effect of certain pre harvest treatments in improving the yield and quality of banana cv. Nanjangudu rasabale. Pl. Arc., 11(2): 677-681.

Pandey, S. N. and Sinha, B. K., 1999, Plant Physiology. Vikas Publ. House Pvt. Ltd., New Delhi.

Ramesh Kumar, A., Kumar, N. and Jeyakumar, P., 2008, Effect of Post-shooting Spray of sulphate of potash (SOP) on yield and quality of Banana cv. Robusta (AAACavendish). Res. J. Agri. Bio. Sci., 4(6): 655-659.

Ramesh Kumar. A. and Kumar. N., 2007, Sulfate of Potash Foliar Spray Effects on Yield, Quality, and Post-Harvest Life of Banana. Better Crops., 91(2): 22-24.

Ranganna, S. 1977, Manual of analysis of fruit and vegetables products. Tata McGrow Hill Publ., Co., Ltd, New Delhi.

Ravichandran, G, Natarajan, N, Manorama, K. and Vanangamudi, K. 2011, Effect of organic sprays on storage behaviour of seed potatoes. Indian J. Hort., 68(3): 399-07.

Sandhya, G.C., Kulapati, H., Patil, S.N., Sadanand, K.M. and Sarvamangala, C., 2016, Effect of post-shooting spray of nitrogen and potassium on bunch characters and fruit yield of banana cv. Grand Naine. The Bioscan., 11(4): 2453-2456.

Sateeshkumar, S. and Bangaruswamy., 2006, Effect of post shooting application of certain nutrients on fruit quality and postharvest storage life of banana cv. Rasthali (AAB). Pl. Arc., 6 (1): 201-204.

Shira, V.D., Singh, S.Y. and Bauri, F.K., 2013, Effect of post shoot application of potassium through bunch feeding on fruit quality characters of banana in West Bengal. J. Crop and Weed., 9(2): 196-197.

Singh, H.P., 2001, Banana. In: Handbook of Horticulture, ICAR publication, New Delhi. 152.

Singh, K. and Chuhan, K.S., 1982, Effect of certain post-harvest treatment on storage life of guava cv. L-49. Haryana J. Hort. Sci., 11(3): 163-167.

Swietlik, D. and Faust, M., 1984, Foliar nutrition of fruit crops. Hort. Rev., 6: 287-355.

Vadivelu, E. and Shanmugavelu, K. G., 1978, Effect of increasing rates of potash on the quality of banana cv. Robusta. Pot. Rev., 24: $1-4$.

\section{How to cite this article:}

Soumya M. Garasangi, S.I. Athani, Hipparagi, Kulapati, T.B. Allolli, J.B. Gopali and Mallikarjun Awati. 2018. Studies on Bunch Feeding on Yield, Post-Harvest Parameters and B: C Ratio in Banana cv. Rajapuri (Musa AAB). Int.J.Curr.Microbiol.App.Sci. 7(02): 3118-3123. doi: https://doi.org/10.20546/ijcmas.2018.702.375 